$\xi=-1$

\title{
Determinant of Intention to Check-Up Back to Doctors at Public Hospital
}

\author{
Sedianingsih $^{1}$, Ririn Tri Ratnasari $^{2} *$ Ari Prasetyo $^{3}$, Imron Mawardi $^{4}$ \\ ${ }^{1,2,3,4}$ Department of Economics, Faculty of Economics and Business, Universitas Airlangga \\ *Corresponding author E-mail: ririnsari@feb.unair.ac.id
}

\begin{abstract}
The purpose of this study is to determine the factors that influence the intention to check up back if it pain to Dr. Soetomo Hospital and Hajj Public Hospital. This research was conducted with a quantitative explorative approach with an analysis design factors. The first stage of this research is exploring the factors that exist in the minds of patients with spreading open questionnaire, having acquired these factors, then the second phase of this study, carried out a survey to patient non BPJS outpatient and inpatient care in Dr. Soetomo Hospital and Hajj Public Hospital. The sampling technique is purposive sampling. Furthermore, the data were processed using factor analysis. The output of this study is an international journal. The results of this study indicate that factors that affect intention to return (check up back) if pain to Dr. Soetomo Hospital and Hajj Public Hospital formed by six factors. Factors that formed called the service factor, the factor of the facility, hospital image factor, the factor of interpersonal relationships, and location factors. Indicators with the highest loading values obtained from the calculation of the rotation factor is an indicator of the X6 in hospital image factor is the hospital that has the most complete medical equipment in the city of Surabaya.
\end{abstract}

Keywords: Factors and Intention to Check up Back If Patients have sickness.

\section{Introduction}

Health problems has become a major requirement along with the increasing the social circumstance, the society increasingly aware of the importance of health. In East Java, Surabaya in particular, the need for health services has increased rapidly. It can be seen based on the information from Surabaya Central Statistics Agency (BPS), showed that health care facilities are available in Surabaya had as many as 1,043 such health facilities including hospitals, health centers, pharmacies, and other health facilities (1).

The Results of the research by Puspitasari and Arifianty (2), stated that patients of hospital $\mathrm{X}$ in Indonesia complained of medical personnel who are less communicative, less friendly personnel, cleanliness less intact, slow service, doctors can rarely be met, damage to facilities, and other complaints. There are still many hospitals which have not been oriented to the needs of the patient (consumer oriented). Therefore, it is important for the hospital management to determine the factors that influence the intention of returning patients to get treatment if sick, not only because it is influenced by the commitment and trust of patients, but this study is expected to find more findings. As the theory of decisionmaking presented by Kotler and Keller(3) said that the factors that influence consumer behavior consists of cultural, social, personal, and psychological

Customer's intention to revisit the same hospital in the next future, give a second chance by using the same hospital again and considering to revisit the hospital in the future (4). The response of individual patients as user of services of the hospital involved in determining success or failure in realizing hospital's mission. Therefore, it needs an assessment from each patient in experiencing the service of hospital. That assessments can be known through the patient's behavior in the future after the use the hospital's services. Thus, there is a need to do research which factors that determine of intention to check up to doctors at public hospital. The results of this study are expected to provide recommendations for the improvement of health services at government hospitals in order not to lose in competition with private hospitals.

\section{Method}

The research design in this study is the quantitative approach. This study used analysis of causal relationships, that is how one variable affects every changes in other variables (5). Research in this second phase will be carried out with a quantitative approach to do pre eliminary exploration test that aims to explore factors that influence the intention of revisit. The sampling technique is done by non-probability sampling with purposive sampling approach with survey techniques (main test) of 300 patients consisted of 150 patients of Dr. Soetomo Hospital and 150 patients of Hajj Public Hospital. Results were analyzed by using factor analysis.

\section{Results and Discussions}

Some key statistics include: Barlett's test of Sphericity, which is used to test the interdependence between the grains are an indicator of a variable or factor. This analysis intends to determine indicators that are not correlated with each other (colinearity) in the population. If proved there are indicators that are correlated then one of these indicators do not need to be analyzed..

While Keiser-Meyer Olkin (KMO) measure of sampling adequacy, is an index number to compare the magnitude of the correlation 
coefficient between observations with a partial correlation coefficient. If the value of KMO small (less than 0.5) shows that the correlation between the indicators can not be explained other indicators and factor analysis is not appropriate to apply.

In Table 5.5 is a value Keiser-Meyer Olkin (KMO) measure of sampling adequacy calculation result is $0.767>0.5$, which means that the correlation between the indicators can explain other indicators and analysis of appropriate factors to be used as an analysis tool.

The result of the calculation of the rotation factor in Table 5.9 shows, there are five factors formed. In the rotation of factors that can be interpreted is that if the loading factor has a value of more than 0.5 .

Here are the results of the calculation of the rotation factor more:

1. The first factor that has a value of more than 0.5 on the indicator $X_{9}, X_{10}, X_{11}, X_{15}, X_{16}, X_{17}$, and $X_{18}$.

2. The second factor that has a value of more than 0.5 on the indicator $\mathrm{X}_{1}, \mathrm{X}_{2}, \mathrm{X}_{3}, \mathrm{X}_{4}$, and $\mathrm{X}_{5}$

3. The third factor that has a value of more than 0.5 on the indicator $\mathrm{X}_{12}, \mathrm{X}_{13}, \mathrm{X}_{14}$, and $\mathrm{X}_{21}$.

4. The fourth factor that has a value of more than 0.5 on the indicator $\mathrm{X}_{6}, \mathrm{X}_{7}$, and $\mathrm{X}_{8}$.

5. The fifth factor that has a value of more than 0.5 on the indicator $\mathrm{X}_{19}$ and $\mathrm{X}_{20}$.

After phase rotation factor, then the next step will perform the naming of factors and interpretation of factors. The purpose of this step to name the factors. Naming each of factors in this study using surrogate methods, the method named factor based on the value of the highest factor loading on each factor formed (Simamora 2008 dalam Tetuko, 2010: 75). Therefore, there are five factors that formed then there are five factors that influence a patient Non BPJS went to a government hospital.

The first factor that has a value of more than 0.5 on the indicator $\mathrm{X}_{9}, \mathrm{X}_{10}, \mathrm{X}_{11}, \mathrm{X}_{15}, \mathrm{X}_{16}, \mathrm{X}_{17}$, and $\mathrm{X}_{18}$. The highest factor loading value lies on $X_{17}$ indicator with the value of 0.755 . The indicator called matched with the doctor. Based on these indicators, the first factor is called by the service factor. Thus the service factors consist of $\mathrm{X}_{9}$ indicator the service of medical team is fast, $\mathrm{X}_{10}$ indicator called medical team were friendly, $X_{11}$ indicator called the administrative process is easy, $X_{15}$ indicator called the doctor on duty are experts, $X_{16}$ indicators namely medical personnels are reliable, $\mathrm{X}_{17}$ indicator namely which is matched to the doctor, and $\mathrm{X}_{18}$ indicator called many doctors are on duty at emergency department.

The second factor that has a value of more than 0.5 on the indicator $\mathrm{X}_{1}, \mathrm{X}_{2}, \mathrm{X}_{3}, \mathrm{X}_{4}$ and $\mathrm{X}_{5}$. The highest factor loading value lies on $X_{1}$ and $X_{2}$ indicators with a loading value of 0.904 . That indicator namely the government hospital had the best orthopedic facilities in Surabaya. Based on these indicators, the second factor is called facilities factor. Thus factors facilities consist of $\mathrm{X}_{1}$ indicator ie medical equipement / facilities are fairly advanced, $\mathrm{X}_{2}$ indicator ie government hospital has the best orthopedic facilities in Surabaya, $\mathrm{X}_{3}$ indicator namely the good quality of drugs, $\mathrm{X}_{4}$ indicator namely the complete facility, and $\mathrm{X} 5$ indicator namely ie hospitals which has the most complete medical equipment in the Surabaya.

The third factor that has a value of more than 0.5 on the indicator $X_{12}, X_{13}, X_{14}$, and $X_{21}$. The highest factor loading value lies on $X_{13}$ indicator, with the loading value of 0.845 , that indicators regard to the hospital is comfortable. Based on these indicators, the third factor is called hospital image factor. Thus hospital image factor consists of $\mathrm{X}_{12}$ indicator nalemy the big or famous hospital, $\mathrm{X}_{13}$ indicator namely hospitals were comfortable, $\mathrm{X}_{14}$ indicators regard to the genuineness of medicine, and $\mathrm{X}_{21}$ indicators namely the hospitals were clean.

The fourth factor that has a value of more than 0.5 on the indicator $\mathrm{X}_{6}, \mathrm{X}_{7}$ and $\mathrm{X}_{8}$. The highest factor loading value lies on $\mathrm{X}_{7}$ indicator, with the loading value of 0.787 , the indicator regard to personal desire (feel confident). Based on these indicators, the fourth factor is called interpersonal relationships factor. Thus the interpersonal relationships factor consist of $\mathrm{X}_{6}$ indicator called check up to the government hospital frequently, $\mathrm{X}_{7}$ indicator is a personal desire (feel more confident), and $\mathrm{X}_{8}$ indicator namely suggested by ie health centers / company.

The fifth factor that has a value of more than 0.5 on the indicator $\mathrm{X}_{19}$ and $\mathrm{X}_{20}$. The highest factor loading value lies on $\mathrm{X}_{19}$ indicator, with the loading value of 0,795 . The indicator refer to the location that close to home. Based on these indicators, the fifth factor is called the location factor. Thus the details of the work consists of a factor $\mathrm{X}_{19}$ indicator that is close to home and indicators $\mathrm{X}_{20}$ is sufficient parking space.

\section{Conclusions}

The first conclusion that can be drawn from the results of the study are factors that affect check up back intentions if ill to Dr. Soetomo Hospital and Hajj Public Hospital formed by six factors. Factors that formed called the service factor, the factor of the facility, hospital image factor, the factor of interpersonal relationships, and location factors. The second Indicators with the highest loading values obtained from the calculation of the rotation factor is an indicator of the X6 in hospital image factor is the hospital that has the most complete medical equipment in the city of Surabaya

This study has some limitations. First, this study only intends to measure the IGI score of all 38 districts/cities in East Java in period between 2011 to 2014 and does not analyze the determinants of the IGI score. Therefore, it seems to be difficult to justify the reason for low IGI scores in all regions. Second, the target value and the maximum conditions for the reverse index are different with the study of McKinley and Min and Xiaolin, hence, sometimes the results will be dissimilar if we adjust those values. Therefore, future research should accommodate the analysis of factors influencing the inclusiveness of economic growth in order to investigate the reasons for the IGI scores.

\section{Acknowledgment}

This work was supported by Faculty of Economics and Business, Universitas Airlangga

\section{References}

[1] BPS. Official statistics news 2017. Available from: http://surabayakota.bps.go.id.

[2] Puspitasari NB, Arifianty MS. PENGARUH KUALITAS PELAYANAN TERHADAP KEPUASAN PASIEN TERHADAP KELUHAN DAN LOYALITAS PASIEN RAWAT INAP. Prosiding SNST Fakultas Teknik. 2016;1(1).

[3] Keller KL, Parameswaran M, Jacob I. Strategic brand management Building, measuring, and managing brand equity: Pearson Education India; 2011

[4] Sornsri S. Antecedents and consequences of relationship quality: a study on private hospitals in Thailand. AU Journal of Management. 2015;13(1).

[5] Indriantoro N, Supomo B. Metodologi penelitian bisnis untuk akuntansi dan manajemen: BPFE; 1999. 